\title{
Opportunities for Agricultural Trade in the Context of the China-Pakistan Economic Corridor
}

\author{
Muhammad Aamir Shahzad \\ Department of Economics, Pakistan Institute of Development Economics (PIDE) \\ Quaid-i-Azam University Campus, Islamabad (44000), Pakistan
}

Amar Razzaq (Corresponding author)

College of Economics and Management, Huazhong Agricultural University

No. 1 Shizishan Street, Hongshan District, Wuhan (430070), P. R., China

E-mail: amar.razzaq@webmail.hzau.edu.cn

Muhammad Aslam

School of Commerce \& Accountancy, Minhaj University, Lahore (54000), Pakistan

Muhammad Faisal Gulzar

School of Commerce \& Accountancy, Minhaj University, Lahore (54000), Pakistan

Muhammad Asad ur Rehman Naseer

Institute of Agricultural and Resource Economics, University of Agriculture

Faisalabad (38000), Pakistan

\begin{abstract}
Nimra Nisar
Department of Education, National University of Modern Languages

H-9 Islamabad (44000), Pakistan
\end{abstract}

Received: January 25, 2019 Accepted: February 9, 2019 Published: March 12, 2019

doi:10.5296/ber.v9i1.14263 URL: https://doi.org/10.5296/ber.v9i1.14263 


\section{Abstract}

The CPEC provides new avenues for agricultural trade between Pakistan and China. In this context, this study aims to explore the opportunities for trade between Pakistan, China, and the Central Asian States. To this end, the study analyzed the structure of agricultural exports and imports of Pakistan with China and the Central Asian States. China's share in the production of agricultural commodities is dominant in the world. China's per acre yield of pulses has the highest position in the world. The structure of Pakistan imports revealed that Pakistan spends billions of rupees on the imports of agricultural commodities. China's import structure revealed that it spends billions of dollars on the imports of maize, wheat, rice, horticultural fruits, and vegetables. The Central Asian states also import wheat, meat products, agricultural inputs, and horticultural commodities from neighboring countries. The export/import volume of China with the Central Asian states has an almost equal share. However, the results indicate that there is a large gap between China and Pakistan's export and import shares. China has a higher share of imports while Pakistan has low export share with China. The study recommends to the policymakers that the volume of export should be increased with China as well as the Central Asian states.

Keywords: Agricultural trade, CPEC, China, Pakistan, Central Asian states

\section{Introduction}

China Pakistan Economic Corridor (CPEC) connects Kashgar from China with Gwadar in Pakistan. CPEC consists of building roads, rail infrastructure, and other development projects. CPEC's objectives in Pakistan are to strengthen the economy and the infrastructure. Moreover, CPEC will enhance trade between Pakistan and China. Currently, the limited trade through land transportation is due to high transportation cost which acts as an implicit tax and restricts trade. The high transportation cost puts Pakistan in comparatively disadvantageous in international markets. However, improved road network can reduce the cost of transportation and curtail travel time. CPEC also connects the northern areas with the markets of Lahore and Peshawar. Pakistan's agriculture can benefit from exporting fruits and vegetables like apples, apricot, and cherries which are produced in northern areas and other parts of the country. Pakistan's volume of trade with China is around $\$ 16$ billion, of which 97\% is carried out through the sea, 2\% through the air and 1\% through land transport (Anonymous, 2016). There is a possibility of increasing trade volume with China under the CPEC. Better transportation infrastructure can also open the Central Asian markets for Pakistan. Therefore, Pakistan has can access more international markets via CPEC.

In recent times, the formation of regional and global strategic movements has led to geo-strategic and geo-economical partnerships among countries. CPEC is one such partnership. The lack of infrastructure restricts agricultural development and growth. Building better infrastructure increases the better use of technology and thus has a positive impact on agriculture growth (Ahmed \& Mustafa, 2014). This research is designed to identify the potential trade areas in which Pakistan can trade with China and the Central Asian states.

The objective of this study is to identify the crops, vegetables and horticultural products that 
can be exchanged with China and other Central Asian countries in return of foreign exchange.

\subsection{The Outlook of Agriculture Sector of Pakistan}

Agriculture sector contributes $19.8 \%$ to GDP and absorbs $42.3 \%$ of the country's labor force. It provides raw material to the industry and is a source of livelihood for rural populations. Agriculture income is vital to farmers in rural areas. In Punjab province, livestock income contributes up to $50 \%$ of farmer's total income (Ashfaq et al., 2015). Unfortunately, during previous years Pakistan's agriculture faced a negative growth rate and its share in GDP and labor force has declined. GDP share declined 5.26\% in 2015-16 as against the last year 2014-15. Further, the share of the labor force declined up-to $2.76 \%$ in 2015-16 as against the previous year. Similarly, cotton and other important crops witnessed a negative growth rate. Moreover, livestock and fisheries sector reported lower growth rate in 2015-16 as against the last year (GoP. 2014-16). The factors such as lower agriculture crops production are the major reason behind declining agriculture growth rate. Part of this declining agriculture growth can also be attributed to the growing disparities in ownership and distribution of land holdings in Pakistan (Naseer et al., 2016). However, the agriculture sector has the potential to increase its production by increasing per acre productivity and efficient utilization of farm inputs (Shahzad et al., 2019). Pakistan is not self-sufficient in the production of many agricultural commodities ${ }^{1}$. Pakistan fulfills domestic deficiency of production through imports from other countries. The country imported gram, moong, pulses, and vegetables from central Asian countries. Rising agriculture imports puts the burden on national exchequers and increasing the trade deficit ${ }^{2}$. Recent studies show that that trade openness has a positive impact on Pakistani exports (Javed et al., 2018a). Further, Pakistan can reduce its trade deficit by reducing the crop imports or importing from least cost countries. Pakistan has the potential to trade with China, as China is specialized in the production of many agricultural commodities like vegetables, tomatoes, onions, ginger, garlic, and other vegetables.

\subsection{China's Comparative Advantage in the World}

China is the world's largest producer of many crops such as apple, chilies, vegetables, and others. Table-1 shows the comparative position of China in the world.

Table 1. China's Production Outlook in the World

\begin{tabular}{|l|l|l|l|l|}
\hline \multicolumn{1}{|c|}{ Crop } & \multicolumn{1}{|c|}{ Worldwide Rank } & $\begin{array}{c}\text { Production } \\
\text { (Million Tones) }\end{array}$ & \multicolumn{1}{c|}{$\begin{array}{c}\text { Area } \\
\text { (Million Hectare) }\end{array}$} & World share (\%) \\
\hline \multicolumn{5}{|c|}{ Horticultural Crops and Fruits } \\
\hline Apple & $1^{\text {st }}$ Largest Producer & 39.68 & 2.41 & 49.10 \\
\hline Bananas & $2^{\text {nd }}$ Largest producer after India & 12.07 & 0.43 & 11.40 \\
\hline Citrus & $1^{\text {st }}$ Largest Producer & 32.57 & 3.02 & 24.10 \\
\hline Mango \& Guava & $2^{\text {nd }}$ largest producer after India & 4.45 & 0.46 & 10.43 \\
\hline \multicolumn{5}{|r|}{ Vegetables } \\
\hline Onions & $1^{\text {st }}$ Largest Producer & 22.30 & 1.02 & 26.31 \\
\hline
\end{tabular}

\footnotetext{
1 These include pulses and perishable commodities.

2 Pakistan imports pulses and vegetables like, tomatoes, onions and pees worth billions of rupees.
} 


\begin{tabular}{|l|l|l|l|l|}
\hline Potatoes & $1^{\text {st }}$ Largest Producer & 96.08 & 5.64 & 24.95 \\
\hline Tomatoes & $1^{\text {st }}$ Largest Producer & 50.55 & 0.98 & 30.93 \\
\hline \multicolumn{4}{|c|}{ Crops } \\
\hline Wheat & $1^{\text {st }}$ Largest Producer & 126.20 & 25.00 & 17.31 \\
\hline Cotton Seed & $2^{\text {nd }}$ Largest producer after India & 18.43 & 4.22 & 23.97 \\
\hline Lentil & $6^{\text {th }}$ largest producer & 0.15 & 0.068 & 3.13 \\
\hline Maize & $2^{\text {nd }}$ largest producer after USA & 215.64 & 35.95 & 21.11 \\
\hline Rice Paddy & $1^{\text {st }}$ Largest Producer & 206.50 & 30.60 & 27.87 \\
\hline Sugarcane & $\begin{array}{l}3^{\text {rd }} \text { largest producer after } \\
\text { Brazil and India }\end{array}$ & 125.61 & 1.73 & 6.61 \\
& & & & \\
\hline
\end{tabular}

Source: Author's estimates, data accessed from Agriculture Marketing Information System (AMIS)

Table 1 shows that China has a leading position in the production of horticultural fruits, vegetables, and crops. China occupies the 1st position in terms of the total production of horticultural fruits crops like apple and citrus. Moreover, China grows the largest proportion of vegetables in the world. Crops like onions, potatoes, and tomatoes have the world's largest production share. Further, China has the world's highest share in the production of wheat and rice crops.

Table 2. China's Yield Comparison with the World

\begin{tabular}{|l|l|l|}
\hline \multicolumn{1}{|c|}{ Crop } & \multicolumn{1}{|c|}{ Worldwide Rank } & Yield (mounds/ acre) \\
\hline Chilies \& Peppers & $2^{\text {nd }}$ Largest producer after India and $11^{\text {th }}$ highest in yield & 68.98 \\
\hline Dates & Ranked 2 ${ }^{\text {nd }}$ in world's highest yield & 126.46 \\
\hline Garlic & $1^{\text {st }}$ Largest Producer and 3 ${ }^{\text {rd }}$ highest in yield & 249.50 \\
\hline Ginger & $2^{\text {nd }}$ Largest producer after India and $3^{\text {rd }}$ highest in yield & 295.08 \\
\hline Gram & Ranked 3 ${ }^{\text {rd }}$ in yield after Israel and Moldova & 35.41 \\
\hline
\end{tabular}

Source: Author’s estimates, data accessed from Agriculture Marketing Information System (AMIS)

China has specialized in the production of chilies and peppers as it is the world's second largest producer of chilies and is ranked 11th in terms of the world's highest per acre yield of chilies. Similarly, the yield of Chinese dates is the second highest in the world. Moreover, China has the third leading yield in garlic, ginger, and grams. Further, China is the world's largest producer of garlic and second largest producer of ginger in the world. Pakistan has the opportunity to trade with China in the form of imports of domestically deficit crops and technology sharing for China's highest yielding crops in the form of high yielding seeds and production methods. To establish a conclusion about the trade of commodities, there is a need to explore the crop imports of Pakistan from other countries.

\section{Agricultural Trade of Pakistan}

\subsection{Pakistan’s Agricultural Imports Structure}

Pakistan is not self-sufficient in the production of many agricultural commodities. Domestic production has a shortfall compared to domestic consumption. This demand and supply gap is 
bridged through imports. Pakistan imports various agricultural commodities from other countries. Table 3 gives the imports of Pakistan in the year 2012-13, 2013-14 and 2014-15.

Table 3. Pakistan's Agricultural Imports (Rs. million)

\begin{tabular}{|l|l|l|l|}
\hline & $2012-13$ & $2013-14$ & $2014-15$ \\
\hline \multicolumn{4}{|c|}{ Horticultural Crops and Fruits } \\
\hline Dates Fresh & 198.9 & 214.2 & 363.973 \\
\hline Dates Dried & 33.98 & 37.64 & 19.66 \\
\hline Grapes Fresh & 1521.23 & 2210.12 & 4631.979 \\
\hline Apple Fresh & 962 & 801.74 & 1155.515 \\
\hline Pomegranate & 328.68 & 775.19 & 737.318 \\
\hline Apricot Fresh & 527.59 & 300.5 & 811.223 \\
\hline Water Melon & 205.28 & 75.05 & 206.98 \\
\hline \multicolumn{5}{|l|}{ Vegetables } \\
\hline Red Chilies & 144.01 & 347.38 & 993.964 \\
\hline Potatoes & 33.76 & 1905.35 & 6118.719 \\
\hline Onion & 3424.82 & 1523.15 & 1229.426 \\
\hline Tomatoes & 11625.54 & 14975.75 & 9533.246 \\
\hline Garlic & 1790.15 & 4024.67 & 4571.578 \\
\hline Ginger & 3082.48 & 4333.31 & 5212.38 \\
\hline Carrot \& turnip & 10.77 & 4.09 & 8.343 \\
\hline Peas Fresh/Chilled & 163.74 & 501.51 & 1119.452 \\
\hline \multicolumn{5}{|l|}{ Crops \& Pulses } \\
\hline Wheat & 672 & 11352 & 18976 \\
\hline Sugar & 501 & 638 & 632 \\
\hline Pulses & 31501 & 31526 & 41448 \\
\hline Gram & 5120.56 & 3205.3 & 3544.6 \\
\hline Mash & 2422.68 & 4553.5 & 5555.594 \\
\hline Masoor & 2600.48 & 6142.6 & 11418.478 \\
\hline Moong & 529.17 & 413.42 & 93.015 \\
\hline & & & \\
\hline
\end{tabular}

Source: Author's estimates, data accessed from Agriculture Marketing Information System (AMIS)

Pakistan imported horticulture fruits of value Rs. 7.92 billion in 2014-15. While it was 4.41 billion in the year 2013-14 which was Rs.3.77 billion in 2012-13. Horticultural ${ }^{3}$ imports increased with time. The percentage growth in the imports of horticultural fruits 2012-13 to 2014-15 was $109.82 \%$. Moreover, the import value of vegetables also increased over time which amounted to Rs.20.27 billion, Rs.27.61 billion and Rs.28.78 billion for the year 2012-13, 2013-14 and 2014-15 respectively. Vegetable ${ }^{4}$ imports increased by $42 \%$ from 2012-13 to 2014-15. The total value of crops \& pulses imported in 2013-14 was Rs.81.66

3 These includes dates, grapes, apples, pomegranate, apricot, and watermelon.

4 Imported vegetables are red chilies, potatoes, onions, tomatoes, garlic, ginger, carrot \& turnip and pees 
billion which was Rs. 43.34 billion in the previous year. Crops \& Pulses ${ }^{5}$ imports increased by $88.4 \%$ from $2012-13$ to $2013-14$.

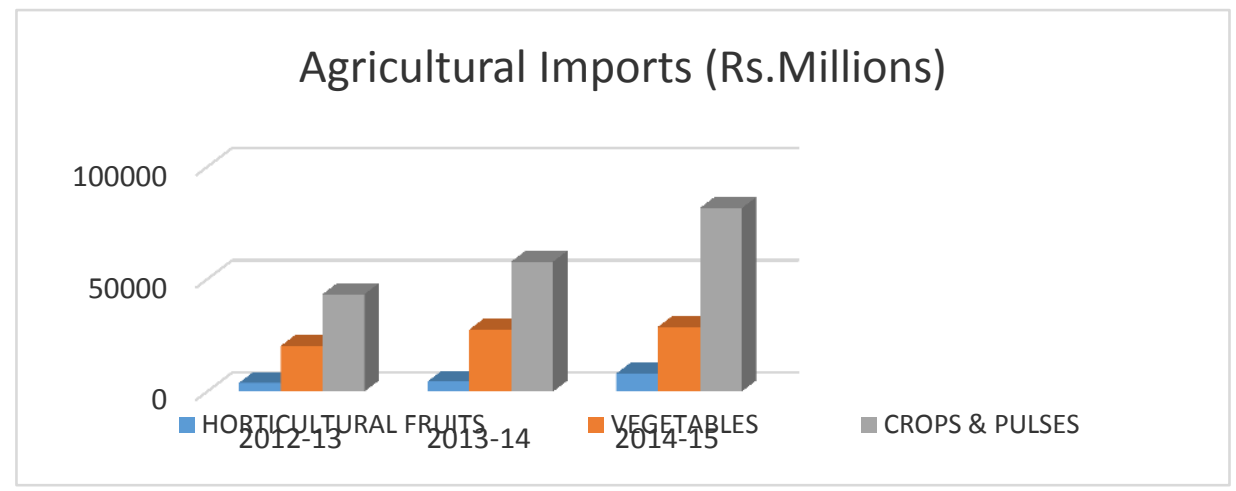

Source: Author's estimates, data accessed from Agriculture Marketing Information System

\subsection{Agricultural Export Structure of Pakistan}

Despite of importing many agriculture commodities, Pakistan earns a considerable amount of foreign exchange through exporting many agricultural commodities. Pakistan is $67^{\text {th }}$ largest exporter of the world. Table 4 shows the exports of crops in Pakistan.

Table 4. Agricultural Exports of Pakistan (Rs. million)

\begin{tabular}{|l|l|l|l|}
\hline & $2012-13$ & $2013-14$ & $2014-15$ \\
\hline \multicolumn{4}{|c|}{ Horticultural Fruits } \\
\hline Kino & $14,563.3$ & $15,665.3$ & $17,385.9$ \\
\hline Mango & $4,706.3$ & $4,976.6$ & $4,627.06$ \\
\hline Apple Fresh & 54.5 & 26.2 & 40.9 \\
\hline Bananas & $2,407.9$ & $2,957.3$ & $1,617.5$ \\
\hline Dates Fresh & 703.4 & $1,494.7$ & $2,091.8$ \\
\hline Dates Dried & $6,657.1$ & $7,507.2$ & $6,244.3$ \\
\hline Guava & 5.5 & 8.4 & 4.8 \\
\hline Grapes Fresh & 0.7 & 3.7 & 236.4 \\
\hline Pomegranate & 11.8 & 9.1 & 7.5 \\
\hline Apricot Fresh & 48.5 & 52.9 & 215.3 \\
\hline Grape Fruit & 0.5 & 0.007 & 1.5 \\
\hline Lemon and Lime & 0.4 & 0.007 & 0.01 \\
\hline Water Melon & 18.5 & 115.6 & 52.7 \\
\hline \multicolumn{5}{|c|}{ Crops } \\
\hline Wheat & 5,126 & 732 & 311 \\
\hline Rice All & 186,623 & 222,885 & 206,254 \\
\hline Rice Basmati & 64,593 & 74,635 & 59,567 \\
\hline Rice Other & 122,030 & 148,250 & 146,687 \\
\hline Sugar & 51,692 & 29,711 & 32,686 \\
\hline \multicolumn{5}{|l}{} \\
\hline \multicolumn{5}{|c|}{} \\
\hline
\end{tabular}

5 Crops \& pulses includes wheat, sugar, pulses gram, mash, moong, masoor 


\begin{tabular}{|l|l|l|l|}
\hline Raw Cotton & 14,882 & 21,353 & 14,937 \\
\hline \multicolumn{4}{|c|}{ Vegetables } \\
\hline Red Chili & 945.06 & 304.4 & 487.8 \\
\hline Potato & $12,290.2$ & $7,985.1$ & $10,295.6$ \\
\hline Onion & $1,357.8$ & $2,011.3$ & $3,707.9$ \\
\hline Tomato & 283.8 & 472.2 & 303.3 \\
\hline Garlic & 25,2 & 9.5 & 30.9 \\
\hline Carrot \& Turnip & 1.4 & 0.9 & 0.3 \\
\hline Pees Fresh/Chilled & 16.2 & 34.1 & 17.2 \\
\hline
\end{tabular}

Source: Author's estimates, data accessed from Agriculture Marketing Information System

Pakistan exports horticultural fruits, crops, and vegetables to different countries. Total horticultural exports in 2014-15 were Rs. 32.52 billion. The horticulture export has declined to (-) $0.88 \%$ as against the growth of $12.5 \%$ in the last year 2013-14. Furthermore, the total value of crops exported in 2014-15 was Rs. 460.44 billion. The export of crops has also declined sharply to (-)7.5\% in $20114-15$ as against the growth of $11.82 \%$ in the last year 2013-14. However, the value of exports derived from vegetables was Rs. 14.84 billion in 2014-15. Vegetable exports have a positive growth rate. The policymakers should pay attention to increase the exports of crops and fruits for which the growth rate is negative.

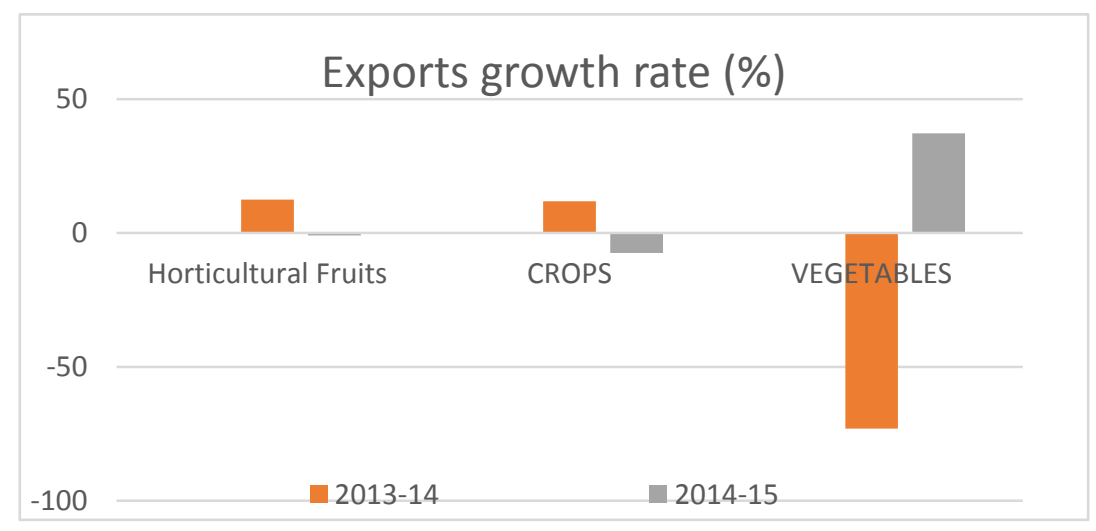

Source: Author's estimates, data accessed from Agriculture Marketing Information System

The study by (Faridi, 2012) revealed that export has a positive relationship with economic growth. Exports are perceived as the engine of economic growth. The study recommended that the government should increase exports in order to increase economic growth in the country. Many other studies are in line with this finding which includes (Balassa, 1985; Feder, 1983; Ram, 1987; Uk Polo, 1994; Voivodas, 1973; Weaver, 1993). These studies found a positive impact of exports on economic growth. Pakistan should increase its exports to achieve economic prosperity in the country. Therefore, this study is designed to identify the potential areas of agriculture in which Pakistan can trade with China and can increase its exports and reduce its expensive imports. In order to achieve this objective, a complete structure of Chinese imports needs to be explored so that the potential of trade can be identified. The following section presents an overview of Chinese imports from other countries. 


\section{Agricultural Trade of China}

\subsection{China's Import Structure}

This section presents the details of China's agricultural imports from other countries. The discussion in this section is based on the available data. The data was collected from various websites. The details are given below;

\subsubsection{Major Crops}

Despite having major shares in the world's production of many agricultural commodities, China also imports from other countries. It has imported Rice and Wheat. Rice import witnessed $\$ 10.51$ billion in the year 2013 and Wheat imports were $\$ 18.65$ billion in the year 2013. The import of wheat is higher than the import of rice. It has also imported cotton lint from of worth $\$ 94.66$ billion in the year 2011 while cotton lint imports in the year 2013 was \$ 89.77 billion Cotton lint import value was declined (-)5.16\% from 2011 to 2013. While import quantity increased from 3.36 million tons to 4.43 million tons from 2011 to 2013. Quantity imported was increased by $31.95 \%$. Hence, the inverse relationship exists between quantity imported and imports value of cotton lint from 2011-2013. Further, prices were responsible for the inverse relationship between quantity imported and the value of imports for cotton lint. China has also imported a considerable quantity of Maize crop in the year 2009, 2011 and 2013. Maize import increased from the year 2011 to the year 2013 cumulatively.

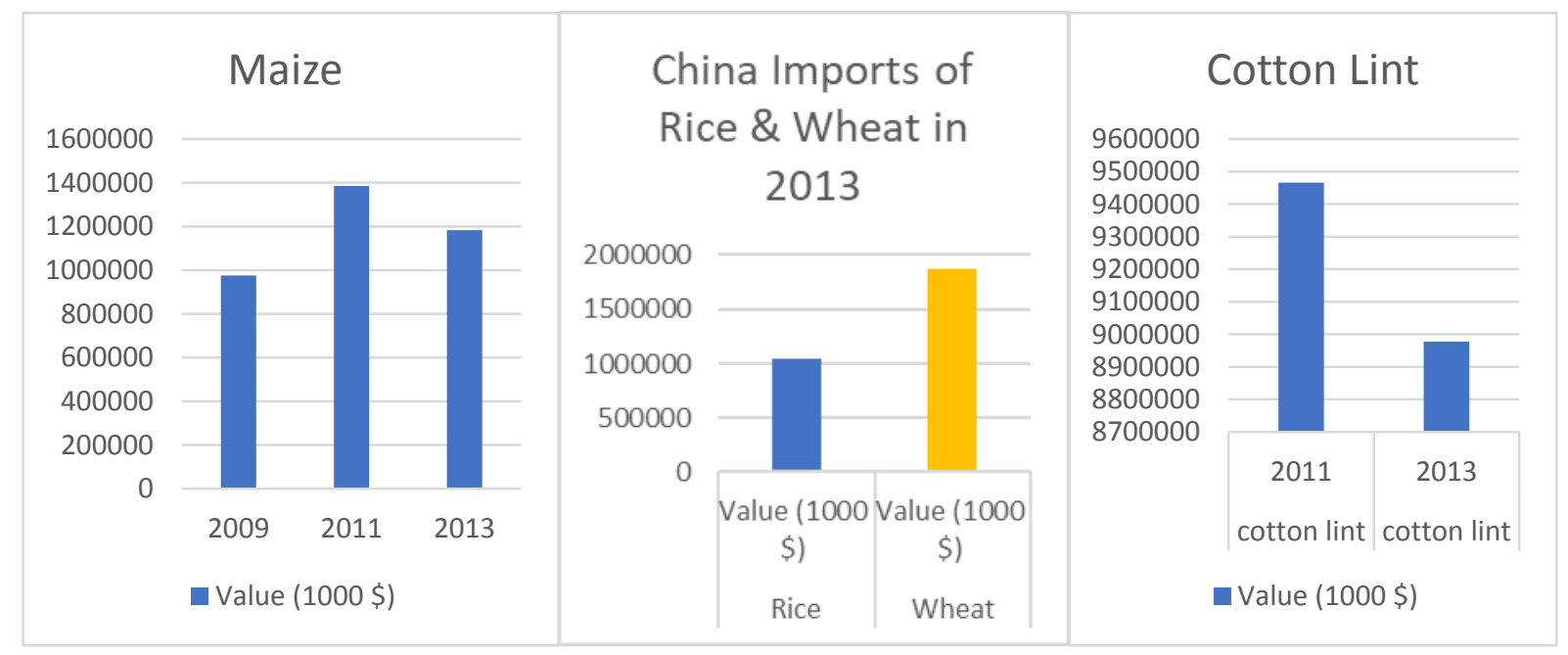

Figure 1. China's Imports of Major Crops 


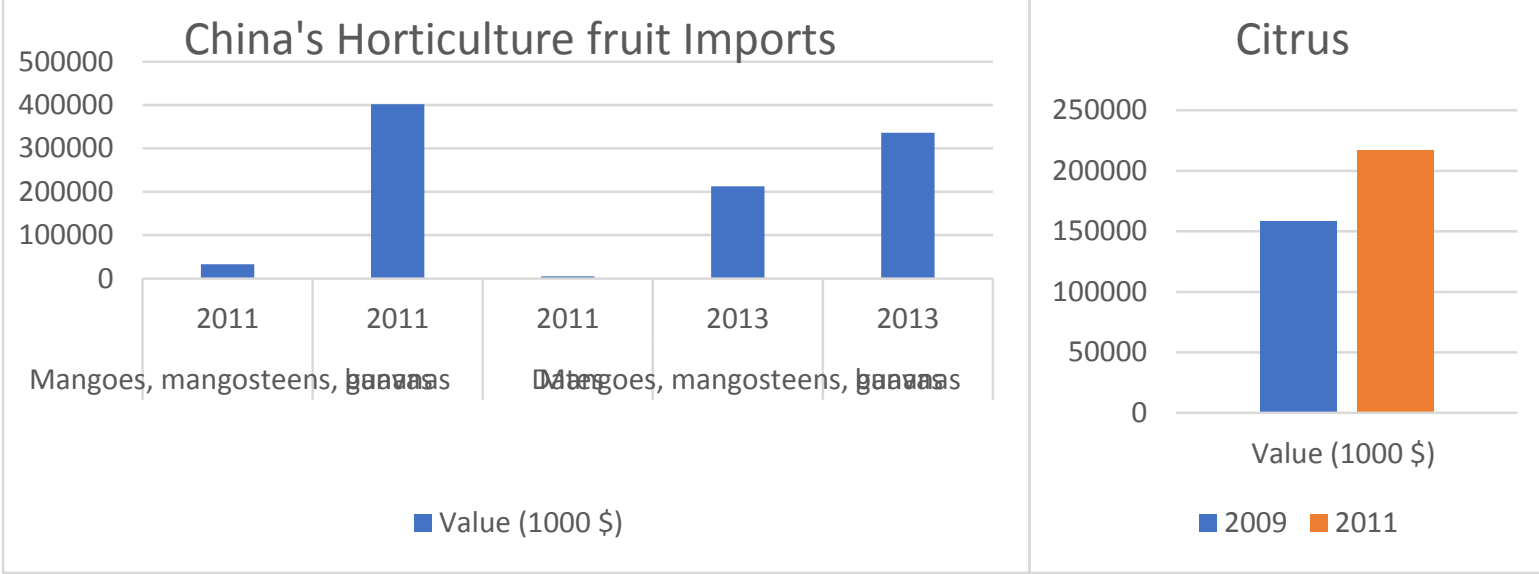

Figure 2. China's horticultural Imports

Source: Author's estimates, data accessed from Agriculture Marketing Information System (AMIS)

\subsubsection{China’s Horticultural Imports}

China import considerable number of horticultural crops like Mango, Guava, Bananas, Dates, and Citrus. Chain's horticultural imports increased with the passage of time. Guava imports has been increased by $544 \%$ from 2011-2013. Its value was $\$ 330.28$ million in 2011-12 which rose to $\$ 2.12$ billion in 2013. Bananas imports were $\$ 4.01$ billion in 2011 and $\$ 3.35$ billion in the year 2013. Bananas imports were reduced to (-)16.38\% in from 2011-2013. Moreover, Citrus imports were $\$ 1.58$ billion in 2011 and $\$ 2.16$ billion in 2013. Citrus imports increased by $36.72 \%$ from 2011-2013. China is also a potential importer of dates.

\section{Pakistan-China Bilateral Trade}

This study categorized Pakistan and China bilateral trade into three categories from 1978 to 2015. Category $1^{\text {st }}$ is from 1978-1988, during this era the bilateral exports and imports were stable and no gap between export and imports existed. However, in category $2^{\text {nd }}$ starting from 1989 to 2002, Pakistan volume of imports with China started to rise. Moreover, the exports were stable and the gap between export and import starts increasing. Category $3^{\text {rd }}$ starts from 2003 and lasts to 2015, in this category the gap between export and imports starts widening. The volume of imports from China to Pakistan was increased sharply while exports initially increased and then after 2012 exports start declining and imports rise to the maximum level. Pakistan exports have declined by 12\% from 2013 to 2015 (Nakhoda, 2017). In China, processing trade is very popular. Chinese domestic firms take raw material and intermediate inputs from other countries, after processing domestically, exports the value-added goods (Yu $\&$ Tian, 2012). Pakistan domestic firms have the potential of value addition in raw material or intermediate inputs. 


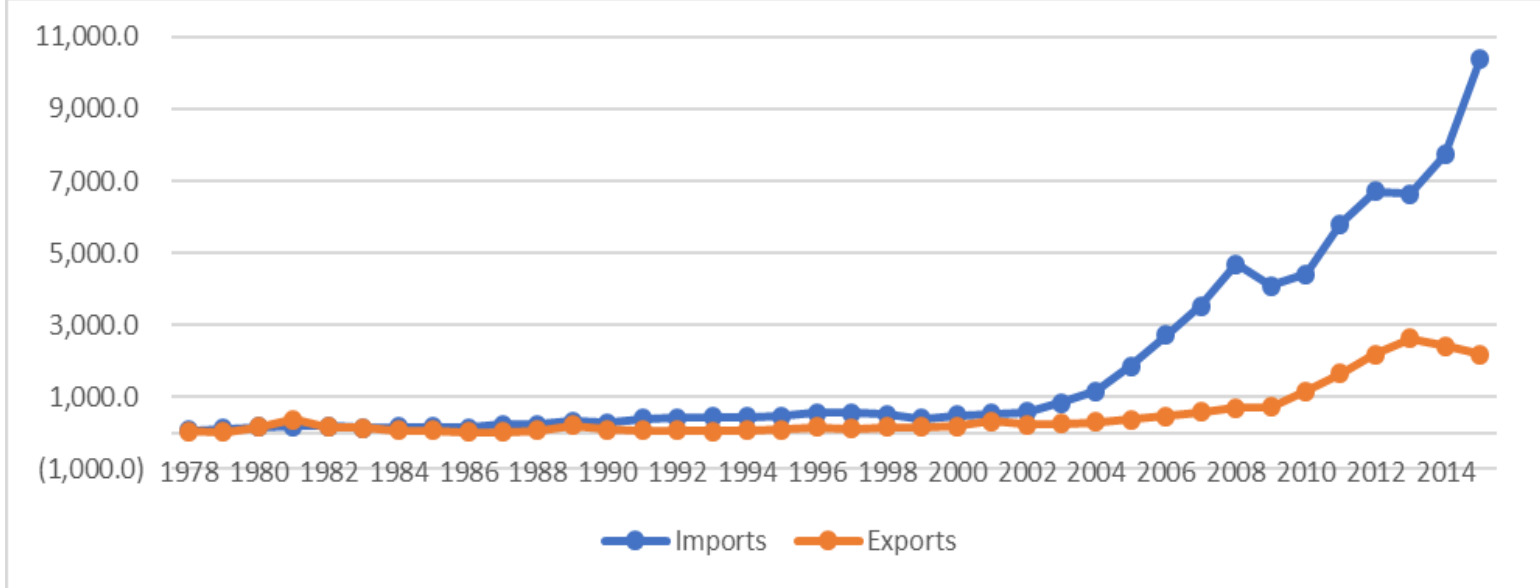

Figure 3. Pakistan and China Export/Import from 1978-2015

Source: State Bank of Pakistan

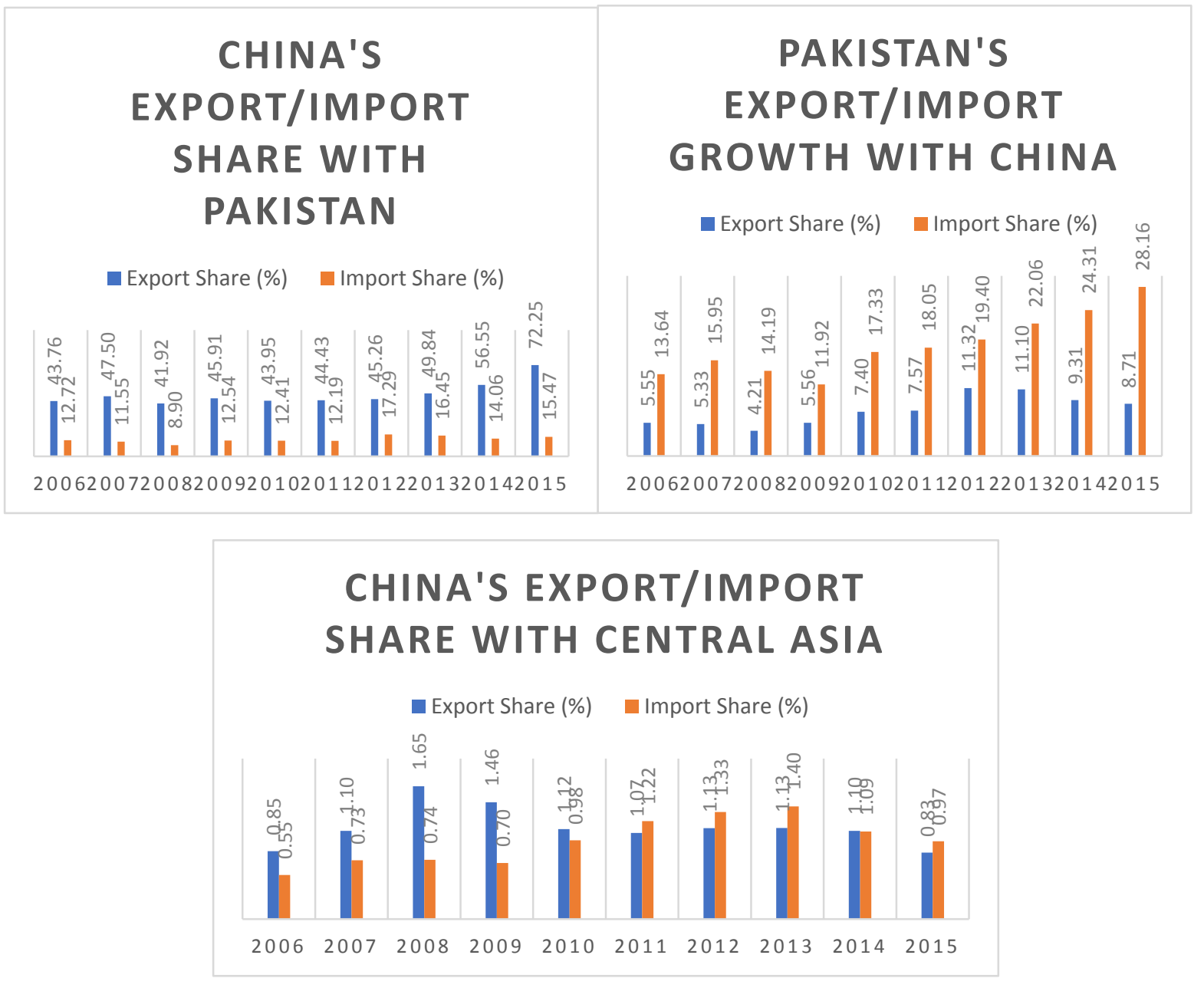

Figure 4. China’s Export/Import Share with Pakistan

Source: Author's estimates from data accessed at www.aric.adb.org

The export-import gap between China and Pakistan is higher than the export-import gap 
between China and the Central Asian states. This export-import gap persists from 2006 to $2015^{6}$. On the other hand, China and the Central Asian states have similar shares of exports and imports. Pakistan's imports from China are higher than Pakistan's exports to China. Pakistan can reduce its trade gap by exporting more products and reducing its imports from China.

Table 5. Bilateral trade of Pakistan and China

\begin{tabular}{|c|c|c|}
\hline \multicolumn{3}{|c|}{ Pakistan's Imports from China } \\
\hline & 2015-16 (Rs. million) & 2014-15 (Rs. million) \\
\hline Livestock $^{7}$ & 16.34 & 124.30 \\
\hline Ornamental $^{8}$ & 0.69 & 0.74 \\
\hline Fishery ${ }^{9}$ & 1.78 & 7.18 \\
\hline Vegetables $^{10}$ & 6372.91 & 4285.69 \\
\hline Horticultural Fruits $^{11}$ & 148.21 & 91.24 \\
\hline Pulses $^{12}$ & 814.38 & 207.17 \\
\hline Tea Products ${ }^{13}$ & 20.67 & 0.12 \\
\hline Agricultural Crops ${ }^{14}$ & 3577.88 & 2289.63 \\
\hline
\end{tabular}

Source: Pakistan Bureau of Statistics

Pakistan' major imports from China consist of livestock, ornaments, fisheries, vegetables, horticultural fruits, pulses, tea products, and crops. Pakistan's volume of import from China is higher for agricultural crops, followed by vegetables, then pulses, horticultural fruits, tea products and then livestock and ornamentals (Table 5). Pakistan can reduce its imports of this commodity and can narrow down the gap between exports and imports by attaining self-sufficiency in the production of these agricultural commodities.

6 China's share of exports with Pakistan was around 72\% in 2015 while Pakistan's share of exports in 2015 was $8.71 \%$. similarly, China's share of imports to Pakistan was $15.47 \%$ in year 2015 while Pakistan's share of import with China in 2015 was $28.16 \%$. However, China's export share with Central Asian states in 2015 was $83 \%$ and import share was $97 \%$. The gap of export and imports was $14 \%$ which is relatively lower than the China's export import share gap with Pakistan that stands at $56.78 \%$ in 2015.

7 Livestock includes the live animal, meat frozen, milk, cream and powder, eggs and animal body parts

${ }^{8}$ Roses and lilies

9 Fisheries include offal, oth, cuttle and aquatic invertebrates

${ }^{10}$ Vegetables include potatoes, garlic, cauli-flower, lettuce, carrots and turnips, pees chilled and dried, beans frozen, sweet corn frozen

${ }^{11}$ Horticultural fruits include dates, citrus, grapes fresh and dried, watermelon, apple fresh, pears and strawberries

${ }^{12}$ Pulses include chick peas, kidney beans, lentils, walnuts and edible nuts

13 Tea products include green tea, black tea, tea dust and black tea packing

14 Agricultural crops include barley, maize, maize corn, rice seed, rice husk, other rice verities, broken rice, grain sorghum, seed millet, other millet, maize corn and cotton seed 
Table 6. Pakistan Export to China (US\$ million)

\begin{tabular}{|l|l|l|l|l|l|}
\hline Commodities & 2011 & 2012 & 2013 & 2014 & 2015 \\
\hline All Products & $1,678.9$ & $2,619.9$ & $2,652.2$ & $2,252.9$ & $1,934.9$ \\
\hline Consumer Goods & 108.0 & 316.5 & 220.3 & 219.9 & 262.4 \\
\hline Intermediate Goods & $1,224.6$ & $1,914.3$ & $2,030.4$ & $1,679.0$ & $1,424.0$ \\
\hline Raw Materials & 332.3 & 377.7 & 373.7 & 332.0 & 234.7 \\
\hline Animal & 416.5 & 40.5 & 36.5 & 55.8 & 46.2 \\
\hline Chemicals & 326.5 & 5.0 & 0.9 & 1.1 & 2.0 \\
\hline Food Products & 23.4 & 30.2 & 43.4 & 66.0 & 96.2 \\
\hline Hides and Skins & 49.4 & 63.5 & 59.5 & 57.6 & 45.1 \\
\hline Textiles and Clothing & $1,175.7$ & $1,878.9$ & $1,986.2$ & $1,592.7$ & $1,326.3$ \\
\hline Vegetables & 40.5 & 330.2 & 203.6 & 224.4 & 207.6 \\
\hline Wood & 0.4 & 0.2 & 0.2 & 0.4 & 0.5 \\
\hline
\end{tabular}

Source: World Bank

Table 7. China imports from world (US\$ million)

\begin{tabular}{|l|l|l|l|l|l|}
\hline Commodities & 2011 & 2012 & 2013 & 2014 & 2015 \\
\hline All Products & $1,743,394.8$ & $1,818,199.2$ & $1,949,992.3$ & $1,958,021.3$ & $1,681,670.8$ \\
\hline Consumer Goods & $188,045.6$ & $205,547.6$ & $214,283.1$ & $231,916.4$ & $204,576.2$ \\
\hline Intermediate Goods & $345,253.0$ & $340,960.2$ & $354,863.0$ & $378,288.4$ & $316,304.2$ \\
\hline Raw Materials & $501,634.6$ & $520,241.3$ & $538,606.8$ & $525,923.0$ & $366,439.9$ \\
\hline Animal & $12,462.0$ & $13,794.2$ & $18,099.3$ & $20,232.4$ & $17,455.6$ \\
\hline Chemicals & $116,853.5$ & $116,844.7$ & $124,328.3$ & $124,124.4$ & $112,152.3$ \\
\hline Food Products & $12,797.1$ & $14,351.9$ & $15,898.5$ & $16,530.4$ & $20,270.2$ \\
\hline Hides and Skins & $9,356.3$ & $9,937.4$ & $11,147.1$ & $11,507.1$ & $11,110.1$ \\
\hline Textiles and Clothing & $37,587.8$ & $40,865.4$ & $40,417.8$ & $35,973.1$ & $32,354.1$ \\
\hline Vegetable & $52,800.1$ & $65,215.3$ & $67,912.7$ & $72,152.8$ & $68,731.1$ \\
\hline Wood & $41,291.4$ & $38,680.8$ & $42,887.2$ & $47,226.6$ & $43,798.9$ \\
\hline
\end{tabular}

Source: World Bank

Pakistan's export to China consists of consumer goods, intermediate goods, raw material, animals, chemical, food products, hide and skins, textile and clothing, vegetables, and wood etc. Despite importing from Pakistan, China also imports these commodities from other countries. Pakistan's share of import of these products is very small as compared with the world. The share of consumer goods, intermediate goods, raw material, animals, chemical, food products, hide and skins, textile and clothing, and vegetables in the year 2015 was 0.12 , $0.13,0.45,0.06,0.27,0.47,0.41,4.10,0.30$, respectively. The share of chemicals and wood is almost zero. Therefore, Pakistan's export to China mainly consist of raw material and unprocessed products. Pakistan has the potential of value addition in raw material and export of value-added products to other countries. In addition, China is the world's second largest 
importer of mutton. However, Pakistani mutton exports to China are negligible. Pakistan can also try to export mutton to China (Javed et al., 2018b).

Table 8. Pakistan's Share to China Imports (\%)

\begin{tabular}{|l|l|l|l|l|l|}
\hline Commodities & 2011 & 2012 & 2013 & 2014 & 2015 \\
\hline All Products & 0.10 & 0.14 & 0.14 & 0.12 & 0.12 \\
\hline Consumer Goods & 0.06 & 0.15 & 0.10 & 0.09 & 0.13 \\
\hline Intermediate Goods & 0.35 & 0.56 & 0.57 & 0.44 & 0.45 \\
\hline Raw Materials & 0.07 & 0.07 & 0.07 & 0.06 & 0.06 \\
\hline Animal & 0.33 & 0.29 & 0.20 & 0.28 & 0.27 \\
\hline Chemicals & 0.03 & 0.00 & 0.00 & 0.00 & 0.00 \\
\hline Food Products & 0.18 & 0.21 & 0.27 & 0.40 & 0.47 \\
\hline Hides and Skins & 0.53 & 0.64 & 0.53 & 0.50 & 0.41 \\
\hline Textiles and Clothing & 3.13 & 4.60 & 4.91 & 4.43 & 4.10 \\
\hline Vegetable & 0.08 & 0.51 & 0.30 & 0.31 & 0.30 \\
\hline Wood & 0.00 & 0.00 & 0.00 & 0.00 & 0.00 \\
\hline
\end{tabular}

Source: World Bank

\subsection{Trading Partners of Pakistan}

The top ten import partner countries of Pakistan are UAE, China, Saudi Arabia, Kuwait, Malaysia, Japan, USA, India, Germany, and Indonesia respectively. Pakistan imports billions of dollars' worth commodities each year from these countries. The share of each country in imports is given in Table 9.

Table 9. Pakistan top 10 Import/Export partners (Product Share \%)

\begin{tabular}{|l|r|r|r|r|c|l|c|c|c|c|c|}
\hline $\begin{array}{l}\text { Import Partner } \\
\text { Countries }\end{array}$ & 2011 & 20102 & 2013 & 2014 & 2015 & $\begin{array}{l}\text { Export Partner } \\
\text { Countries }\end{array}$ & 2011 & 2012 & 2013 & 2014 & 2015 \\
\hline $\begin{array}{l}\text { United Arab } \\
\text { Emirates }\end{array}$ & 15.6 & 16.46 & 17.7 & 14.8 & 13.0 & United States & 15.1 & 14.9 & 14.9 & 14.7 & 16.5 \\
\hline China & 14.8 & 15.26 & 15.1 & 20.1 & 25.0 & Afghanistan & 10.5 & 8.53 & 7.95 & 7.6 & 7.8 \\
\hline Saudi Arabia & 10.7 & 9.78 & 8.79 & 9.29 & 6.84 & $\begin{array}{l}\text { United Arab } \\
\text { Emirates }\end{array}$ & 7.58 & 11.6 & 7.07 & 5.36 & 4.07 \\
\hline Kuwait & 8.93 & 9.61 & 9.02 & 6.22 & 3.89 & China & 6.62 & 10.6 & 10.5 & 9.11 & 8.76 \\
\hline Malaysia & 6.26 & 4.87 & 4.39 & 2.69 & 2.07 & Germany & 5.18 & 4.02 & 4.3 & 4.92 & 5.19 \\
\hline Japan & 4.27 & 4.28 & 4.48 & 3.69 & 3.92 & $\begin{array}{l}\text { United } \\
\text { Kingdom }\end{array}$ & 4.97 & 5.07 & 5.7 & 6.69 & 7.12 \\
\hline United States & 4.02 & 3.45 & 3.81 & 3.79 & 4.36 & Bangladesh & 3.74 & 2.83 & 2.86 & 2.78 & 3.17 \\
\hline India & 3.69 & 3.59 & 4.28 & 4.43 & 3.79 & Italy & 3.07 & 2.12 & 2.55 & 3.1 & 2.8 \\
\hline Germany & 2.3 & 2.61 & 3.28 & 2.25 & 2.21 & Turkey & 2.98 & 1.69 & 1.62 & 1.58 & 1.07 \\
\hline Indonesia & 2.13 & 3.08 & 2.76 & 4.43 & 4.64 & Belgium & 2.59 & 2.01 & 2.28 & 2.66 & 2.68 \\
\hline
\end{tabular}

Source: World Bank accessed at www.witz.worldbank.org 


\section{Al Macrothink}

Business and Economic Research ISSN 2162-4860 2019, Vol. 9, No. 1

Pakistan's top ten export partner countries are USA, Afghanistan, UAE, China, Germany, UK, Bangladesh, Italy, Turkey and Belgium, respectively. The share of Pakistan's export to these countries is given in detail in Table 9 .

\subsection{Trading Partners of China}

China's top ten import partner countries include Japan, Korean Republic, USA, Germany, Australia, Malaysia, Brazil, Saudi Arabia, Russian Federation, and Thailand respectively. India is the $21^{\text {st }}$ importing partner of China while Pakistan stands at $56^{\text {th }}$ position. China's top ten export partner countries include USA, Hong Kong, Japan, Korean Republic, Germany, Netherlands, India, the UK, Russia, and Singapore. Pakistan is China's top $35^{\text {th }}$ export partner country. The details of the import and export products share is given in Table 10.

Table 10. China's top 10 Import/Export partners (Product share \%)

\begin{tabular}{|l|l|l|l|l|l|l|l|l|l|l|l|}
\hline $\begin{array}{l}\text { Import Partner } \\
\text { Countries }\end{array}$ & 2011 & 2012 & 2013 & 2014 & 2015 & $\begin{array}{l}\text { Export Partner } \\
\text { Countries }\end{array}$ & 2011 & 2012 & 2013 & 2014 & 2015 \\
\hline Japan & 11.16 & 9.78 & 8.32 & 8.32 & 8.51 & United States & 17.12 & 17.2 & 16.71 & 16.95 & 18 \\
\hline Korean Republic & 9.33 & 9.28 & 9.39 & 9.71 & 10.38 & Hong Kong & 14.12 & 15.79 & 17.41 & 15.5 & 14.65 \\
\hline United States & 7.06 & 7.36 & 7.87 & 8.16 & 8.95 & Japan & 7.81 & 7.4 & 6.8 & 6.38 & 5.96 \\
\hline Germany & 5.32 & 5.06 & 4.83 & 5.36 & 5.21 & $\begin{array}{l}\text { Korean } \\
\text { Republic }\end{array}$ & 4.37 & 4.28 & 4.13 & 4.28 & 4.45 \\
& & & & & & & & & \\
\hline Australia & 4.74 & 4.65 & 5.07 & 4.99 & 4.39 & Germany & 4.02 & 3.38 & 3.05 & 3.1 & 3.03 \\
\hline Malaysia & 3.56 & 3.21 & 3.08 & 2.84 & 3.17 & Netherlands & 3.13 & 2.87 & 2.73 & 2.77 & 2.61 \\
\hline Brazil & 3 & 2.88 & 2.78 & 2.64 & 2.64 & India & 2.66 & 2.33 & 2.19 & 2.31 & 2.55 \\
\hline Saudi Arabia & 2.84 & 3.02 & 2.74 & 2.48 & 1.79 & $\begin{array}{l}\text { United } \\
\text { Kingdom }\end{array}$ & 2.32 & 2.26 & 2.31 & 2.44 & 2.61 \\
\hline Russian Federation & 2.32 & 2.43 & 2.03 & 2.13 & 1.98 & $\begin{array}{l}\text { Russian } \\
\text { Federation }\end{array}$ & 2.05 & 2.15 & 2.25 & 2.29 & 1.53 \\
\hline Thailand & 2.24 & 2.12 & 1.98 & 1,96 & 2.21 & Singapore & 1.87 & 1.99 & 2.07 & 2.09 & 2.33 \\
\hline South Africa $\left(11^{\text {th }}\right)$ & 1.84 & 2.48 & 2.48 & 2.28 & 1.80 & Pakistan $\left(35^{\text {th }}\right)$ & 0.44 & 0.45 & 0.5 & 0.57 & 0.72 \\
\hline
\end{tabular}

Source: World Bank, accessed at www.witz.worldbank.org

\section{Central Asian Markets for Agricultural Products}

Central Asia is the region of countries like Kazakhstan, Kyrgyzstan, Tajikistan, Uzbekistan, and Turkmenistan. Central Asian states are willing to join the CPEC project. There is a large scope for trade in textile, cotton products, food items, and others through CPEC (Anoymous, 2015). Agriculture is losing its central position in these countries. The rate of agriculture imports is higher than the exports and countries rely on imports for fulfilling domestic consumption. Figure 5 below gives the demand and supply prospects of grain crops in these countries. 


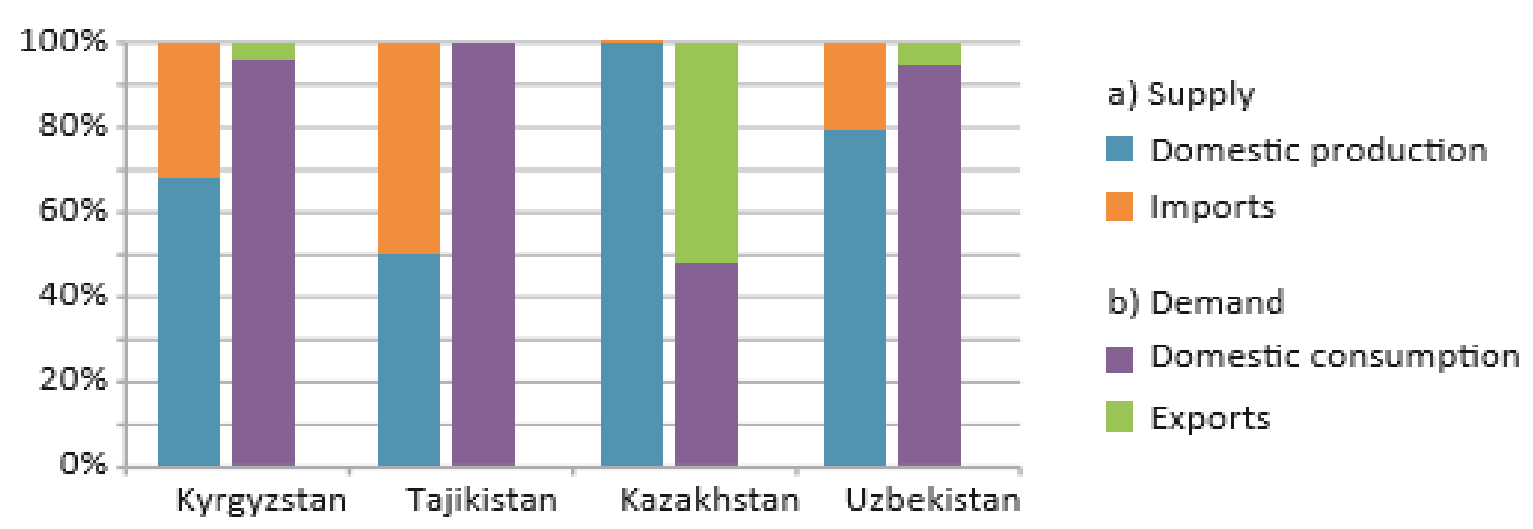

Figure 5. Prospectus of Grain in Central Asia

Source: (Mogilevskii \& Kamiljon, 2014)

Domestic consumption of grain for Kyrgyzstan is fulfilled through imports. Moreover, Tajikistan fulfills around $50 \%$ of domestic consumption through imports. However, Kazakhstan produced sufficiently and exported around $49 \%$ of grain to other states. Further, Uzbekistan import volume for grain is relatively lower than other Central Asian states. In a nutshell, Central Asian states Kyrgyzstan, Tajikistan, and Uzbekistan strongly depend upon imports for fulfilling domestic consumption.

Analysis of the product structure of agricultural commodity showed that the Central Asian states have prepared food share of 30-40\% in total agriculture imports. Kyrgyzstan, Tajikistan, and Uzbekistan import wheat grain and wheat flour in large quantities. These countries also import meat, fats, fertilizer, and oils from other countries. 
a) Kazakhstan - Exports

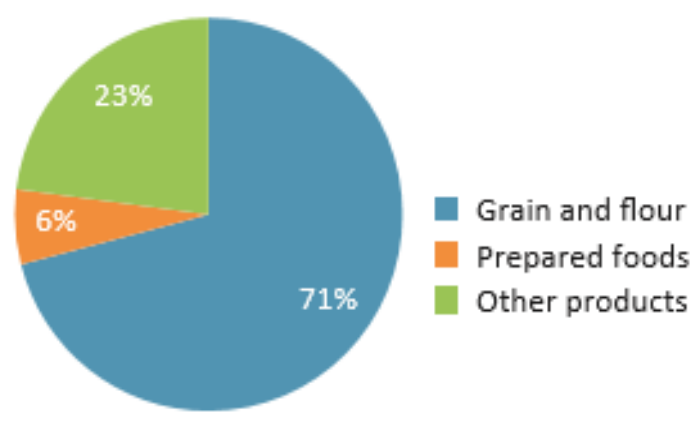

c) Kyrgyzstan - Exports

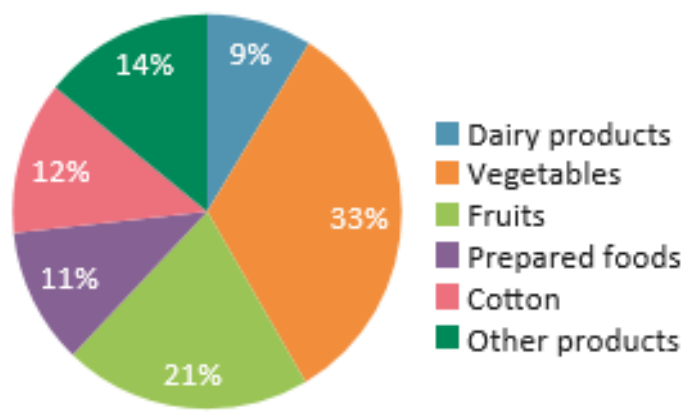

b) Kazakhstan - Imports

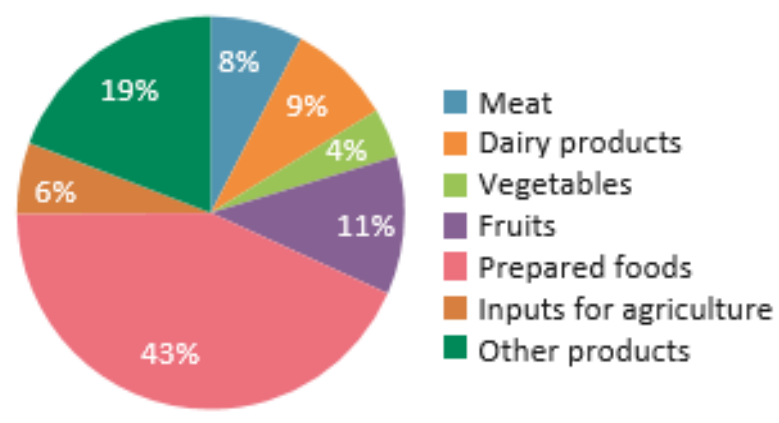

d) Kyrgyzstan - Imports

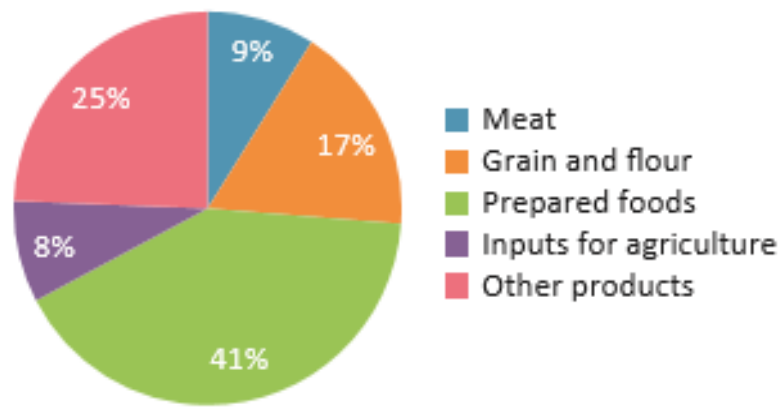

Figure 6. Export/Import Structure of Kazakhstan and Kyrgyzstan

Source: (Mogilevskii \& Kamiljon, 2014)

The analysis revealed that the Central Asian trade is concentrated in few commodities. Only wheat and cotton have almost 50\% of agriculture food exports in countries such as Kazakhstan, Tajikistan, and Uzbekistan. The larger proportion of export of Uzbekistan is comprised of fertilizers. Further, Kazakhstan and Kyrgyzstan export the prepared food including beverages. Vegetables and fruits exports are dominant in countries like Kyrgyzstan, Tajikistan, and Uzbekistan.

In a nutshell, Uzbekistan, Tajikistan, Kyrgyzstan, and Kazakhstan imports are based on the products including grain and flour, prepared foods, fats and oils. Also, Tajikistan, Kyrgyzstan, and Kazakhstan also import meat. Moreover, Kyrgyzstan and Kazakhstan import input of agriculture. Further, Kazakhstan imports fruits, vegetables, and dairy products. 
e) Tajikistan - Exports

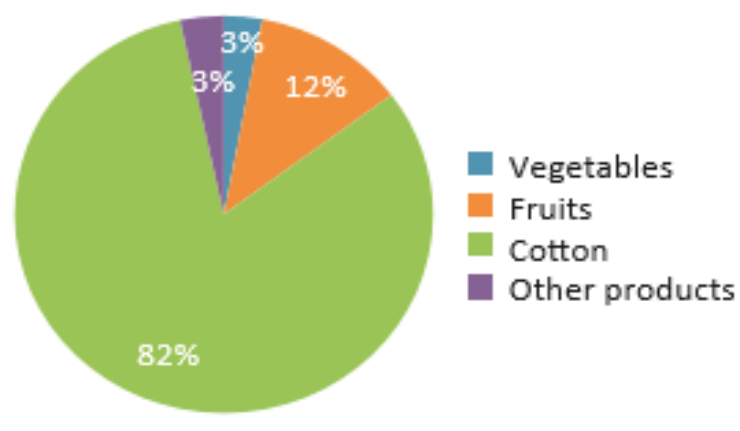

g) Uzbekistan - Exports

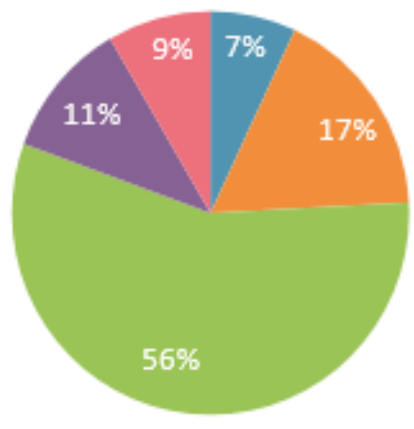

f) Tajikistan - Imports

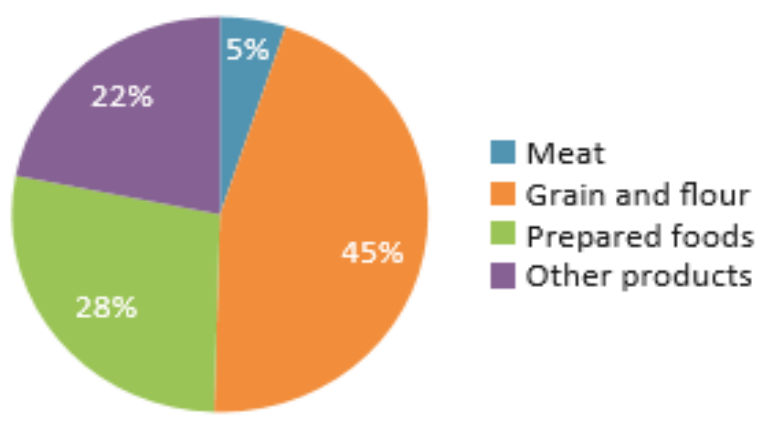

h) Uzbekistan - Imports

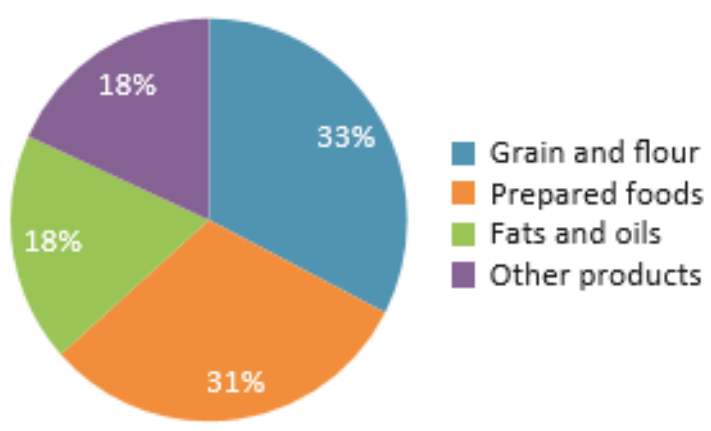

Figure 7. Export/Import Structure of Tajikistan and Uzbekistan

Source: (Mogilevskii \& Kamiljon, 2014)

\section{Pakistan's Competitiveness in Crops}

Pakistan is the fourth largest producer of fiber and seventh largest producer of the wheat crop in the world. Moreover, sugarcane is ranked $11^{\text {th }}$ and Rice and Citrus are ranked $13^{\text {th }}$ worldwide. Further, cereal and pulses rank $16^{\text {th }}$ and oil crops and fruits have the $21^{\text {st }}$ largest share in total production of the world. Vegetables and jute and jute like products have the $24^{\text {th }}$ largest share in world production.

Table 11. Pakistan competitive position in the world

\begin{tabular}{|l|l|l|l|}
\hline Crop & World position & Crop & World position \\
\hline Fiber Crop & $4^{\text {th }}$ Largest & Pulses & $16^{\text {th }}$ Largest Producer \\
\hline Wheat & $7^{\text {th }}$ Largest Producer & Oil Crops & $21^{\text {st }}$ Largest Producer \\
\hline Sugarcane & $11^{\text {th }}$ Largest Producer & Fruit & $21^{\text {st }}$ Largest Producer \\
\hline Rice & $13^{\text {th }}$ Largest Producer & Vegetables & $24^{\text {th }}$ Largest Producer \\
\hline Citrus Fruit & $13^{\text {th }}$ Largest Producer & Jute and Jute-like Products & $24^{\text {th }}$ Largest Producer \\
\hline Cereal & $16^{\text {th }}$ Largest Producer & & \\
\hline
\end{tabular}

Source: Food and Agriculture Organization 


\section{Conclusions and Policy Implications}

The objective of this study was to explore the trade possibilities among China, Pakistan and the Central Asian states. The structural analysis of agricultural trade carried out for these countries. The results revealed that China is the world's largest producer of agricultural commodities. Moreover, China has the highest share in production and the yield of major cops as well as the perishable cops. As far as it is concerned for Pakistan, the results indicate that the substantial amounts of foreign reserves are spent by Pakistan on imports of agricultural commodities including grain and perishable commodities.

The trade potential exists for China to export its grain and perishable cops to Pakistan, while Pakistan can export maize, wheat, rice, horticultural fruits, and vegetables to China because China imports sizeable amounts of these commodities. These items can also be supplied to central Asian states as these agricultural commodities retain the high demand for import. Finally, Pakistan's export share is lower with China. Therefore, it is recommended that policymakers may focus on increasing the volume of export with China. In addition, China has the highest level of production share in the world in agricultural crops. Pakistan can trade with China on domestically deficit commodities.

We recommend the following import-based policy options:

- Policymakers should pay attention to import vegetables especially pulses from China.

- Policymakers should pay attention to import high yielding seed and production methods/technology of pulses and vegetables from China so that per acre yield in Pakistan can be increased.

There are following export-based policy recommendations that emerge from this study:

China imports some agricultural commodities from other countries. Pakistan has the potential to export agricultural commodities to China. Therefore;

- Pakistan should pay attention to export maize to China

- The focus should be to increase the volume of export of cotton lint and processed cotton to China after fulfilling domestic deficiency.

- Wheat and rice can also be exported to China.

- Pakistan can export horticultural crops and fruits to China after fulfilling domestic deficiency.

Finally, we recommend the following policy options for the Central Asian markets:

- Potential of export for wheat and rice exists in Uzbekistan, Tajikistan, Kyrgyzstan, and Kazakhstan.

- The export potential exists for meat products in Tajikistan, Kyrgyzstan, and Kazakhstan.

- Agricultural inputs especially farm implements can be exported to Kyrgyzstan and Kazakhstan.

- Horticulture fruits and vegetables can be exported to Kazakhstan. 


\section{Acknowledgement}

The authors acknowledge the support of Agricultural Marketing Information Systems (AMIS), Lahore for providing data for this research.

\section{References}

Ahmed, R., \& Mustafa, U. (2014). Impact of CPEC projects on agriculture sector of Pakistan: Infrastructure and agricultural output linkages. Pakistan Institute of Development Economics.

Anonymous. (2016). CPEC: trade prospects. Pakistan Observer. [Online] Available: http://pakobserver.net/cpec-trade-prospects/

Anoymous. (2015). Kazakhstan shows willingness to join CPEC project. The News. [Online] Available:

https://www.thenews.com.pk/print/14270-kazakhstan-shows-willingness-to-join-cpec-project

Ashfaq, M., Razzaq, A., Haq, S. U., \& Muhammad, G. (2015). Economic analysis of dairy animal diseases in Punjab: a case study of Faisalabad district. Journal of Animal and Plant Sciences, 25(5), 1482-1495.

Balassa, B. (1985). Exports, policy choices, and economic growth in developing countries after the 1973 oil shock. Journal of Development Economics, 18(1), 23-35.

https://doi.org/10.1016/0304-3878(85)90004-5

Volume 18, Issue 1, May-June 1985, Pages 23-35

Faridi, M. Z. (2012). Contribution of agricultural exports to economic growth in Pakistan. Pakistan Journal of Commerce Social Sciences, 6(1), 133-146.

Feder, G. (1983). On Exports and Economic Growth. Journal of Development Economics, 12(1-2), 59-73. https://doi.org/10.1016/0304-3878(83)90031-7

Javed, I., Nabi, I., Yasin, M., \& Razzaq, A. (2018a). Macro determinants of exports from Pakistan to United Arab Emirates (UAE): An empirical analysis. Journal of Agricultural Research, 56(2), 209-214.

Javed, I., Razzaq, A., Yasin, M., Imran, M. A., Javaid, H., Nabi, I., . . Ahmad, S. (2018b). Mutton export competitiveness of Pakistan. Pakistan Journal of Agricultural Research, 31(4), 313-322.

Mogilevskii, R., \& Kamiljon, A. (2014). Trade in agricultural and food products in Central Asia. Institute Of Public Policy And Administration Working Paper No.27. [Online] Available: https://papers.ssrn.com/sol3/papers.cfm?abstract_id=2946713.

Nakhoda, A. (2017). The declining trend in Pakistan's exports. The Express Tribune. [Online] Available:

https://tribune.com.pk/story/1281245/assessment-declining-trend-pakistans-exports 


\section{Macrothink}

Business and Economic Research

ISSN 2162-4860 2019, Vol. 9, No. 1

Naseer, A., Ashfaq, M., Abid, M., Razzaq, A., \& Hassan, S. (2016). Current status and key trends in agricultural land holding and distribution in Punjab, Pakistan: implications for food security. Journal of Agricultural Studies, 4(4), 14-27. doi:doi.org/10.5296/jas.v4i4.9670

Ram, R. (1987). Exports and economic growth in developing countries: evidence from time-series and cross-section data. Economic Development and Cultural Change, 36(1), 51-72. https://doi.org/10.1086/451636

Shahzad, M. A., Razzaq, A., Aslam, M., Gulzar, M. F., Naseer, M. A. U. R., \& Nisar, N. (2019). Measuring Technical Efficiency of Wheat Farms in Punjab, Pakistan: A Stochastic Frontier Analysis. Journal of Agricultural Studies, 7(1), 115-127. doi:doi.org/10.5296/jas.v7i1.14239

Uk Polo, V. (1994). Export composition and growth of selected low-income African countries: Evidence from time-series data. Applied Economics, 26(5), 445-449. https://doi.org/10.1080/00036849400000012

Voivodas, C. S. (1973). Exports, foreign capital inflow and economic growth. Journal of International Economics, 3(4), 337-349. https://doi.org/10.1016/0022-1996(73)90026-3

Weaver, J. H. (1993). Exports and economic growth in a simultaneous equations model. The Journal of Developing Areas, 27(3), 289-306.

Yu, M., \& Tian, W. (2012). China's processing trade. East Asia Forum. https://doi.org/10.22459/RSGC.07.2012.06

\section{Copyright Disclaimer}

Copyright for this article is retained by the author(s), with first publication rights granted to the journal.

This is an open-access article distributed under the terms and conditions of the Creative Commons Attribution license (http://creativecommons.org/licenses/by/3.0/). 